\title{
Mesotrione use for selective post-emergence control of glyphosate-resistant Conyza spp. in black oats
}

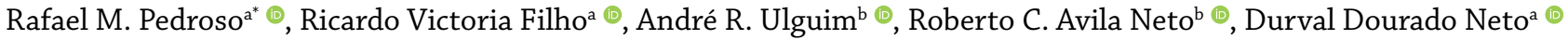 \\ ${ }^{a}$ Crop Science Department, University of Sao Paulo (ESALQ/USP), Piracicaba, SP, Brazil. bRural Science Center, Federal University of Santa Maria \\ (UFSM), Santa Maria, RS, Brazil.
}

\begin{abstract}
Background: Achieving satisfactory weed control levels in black oat (Avena strigosa) fields is often difficult, owing to the limited number of registered herbicide molecules.

Objective: To determine novel options for selective, post-emergence chemical weed control in this crop.

Methods: Eight herbicide treatments were sprayed in the field onto black oat plants at the tillering stage to evaluate crop safety and control of Conyza spp. and Gamochaeta americana, two major weeds of Brazilian black oats. A separate trial was conducted to further assess herbicide safety in a controlled-environment setting, and mesotrione selectivity was then re-evaluated separately in the greenhouse during the following growing season. Crop phytotoxicity was determined using biomass production both in the field and in greenhouse trials.
\end{abstract}

Results: Mesotrione, bentazon, 2,4-D, and a 2,4-D+bentazon tankmix produced light symptoms of crop phytotoxicity, from which plants quickly recovered. Conyza spp. control was achieved via applications of mesotrione (192 g a.i. ha ${ }^{-1}$ ), metsulfuron-methyl (3.9 g a.i. ha $\left.{ }^{-1}\right)$, and a 2,4-D + bentazon tank-mix (502.5 g a.e. ha ${ }^{-1}+720$ g a.i. ha ${ }^{-1}$, respectively), whereas proper G. americana control was only achieved via applications of either mesotrione or metsulfuron-methyl. Biomass accumulation by black oat plants in the greenhouse was similar across mesotrione-treated and untreated plants.

Conclusions: Mesotrione could become an option for selective, postemergence weed control in black oat fields, aiding in the fight against multiple herbicide-resistant Conyza spp. populations which are widespread across major black oat-growing areas in Brazil.

Keywords: U46; Avena strigosa Schreb; bentazon; herbicides; HPPD; metsulfuron-methyl

Journal Information:

ISSN - 2675-9462

Website: http://awsjournal.org

Journal of the Brazilian Weed Science Society

How to cite: Pedroso RM, Victoria Filho R, Ulguim AR, Avila Neto RC, Dourado Neto D. Mesotrione use for selective post-emergence control of glyphosate-resistant Conyzo spp. in black oats. Adv Weed Sci. 2021:e20210026.

https://doi.org/10.51694/AdvWeedSci/2021;39:00021

Approved by:

Editor in Chief: Anderson Luis Nunes Associate Editor: Silvia Fogliatto

Conflict of Interest: The authors declare that there is no conflict of interest regarding the publication of this manuscript.

Received: March 20, 2021

Approved: November 19, 2021

* Corresponding author: <rmpedroso@usp.br>

\section{(c) (4)}

This is an open-access article distributed under the terms of the

Creative Commons Attribution License, which permits unrestricted use, distribution, and reproduction in any medium, provided that the original author and source are credited.

Copyright: 2021

\section{Introduction}

Herbicide usage represents an inexpensive, efficient option for weed management in crops and pastures, delaying the onset of the critical period of weed interference and increasing productivity (Hussain et al., 2011). Weed allelopathy and competition for resources are known to decrease biomass production in forage species, from establishment to regrowth stages. The elimination of toxic weed species in pastures is also a major advantage related to herbicide applications, hence lowering the risk of intoxication or even death which could follow biomass ingestion by farm animals (Russell et al., 2018).

Black oats (Avena strigosa Schreb), also referred to as Japanese or bristle oats, are an annual, $\mathrm{C}_{3}$-type grass species which resemble common oats (Avena sativa L., also referred to as white or yellow oats); however, plants of the former are larger and deeper rooting (Martins et al., 2016). This cold-adapted crop is commonly grown in southern Brazil in late autumn and winter months and primarily used for forage purposes, grown either singular (as a single crop) or in consortium with other forage species, or as cover cropping to provide biomass mulch for direct seeding of summer crops. Black oats have become increasingly popular in direct-seeded systems due to its elevated tillering capacity, low soil fertility requirements, and large production of slow-decaying biomass which greatly suppress growth of several weed species (Oliveira Neto et al., 2010). A combined total of nearly 430,000 ha were cultivated in 2020 with either common oats, black oats, short oats (Avena brevis Roth), or red oats (Avena byzantina K.Koch) in Brazil, which represents a 400\% increase in just 13 years (Companhia Nacional de Abastecimento, 2021).

In Brazil, three troublesome species in the Conyza genus (syn. Erigeron; horseweed or fleabane) constitute major weeds of summer crops such as soybeans (Glycine max (L.) Merr.) and maize (Zea mays L.): Conyza canadensis (L.) Cronquist, C. bonariensis (L.) Cronquist, and C. sumatrensis (Retz.) E. Walker. The latter, commonly named Sumatran fleabane or tall fleabane (Figure 1D), is native to Brazil and South America but has spread to all continents (Borges et al., 2015; Pruski, Sancho, 2006), suggesting strong invasiveness capabilities which might be related to its elevated production of small, easily-dispersed seeds which germinate rapidly (Hao et al., 2009). C. sumatrensis has recently developed resistance to multiple herbicides in this country, including a 
unique, worrisome case of resistance to 2,4-D due to rapid necrosis (Heap, 2021; Queiroz et al., 2020).

Similarly to Conyza spp., Gamochaeta americana (Mill.) Wedd. (syn. Gnaphalium coarctatum Willd. or Gamochaeta coarctata (Willd.) Kerguélen), commonly named gray everlasting (Figure 1E), is also a member of the Asteraceae (sunflower) family. Such species is native to the Americas, occurring in the Central Brazilian Savanna, Atlantic Rainforest, and Pampa regions (Loeuille, 2020). Despite being present in carrots (Daucus carrota L.) and sugarcane (Saccharum officinarum L.)-growing fields, G. americana represents a more serious threat to soybeans, maize, common oats, and wheat (Triticum aestivum L.) production in Brazil (Piza et al., 2016).

Currently, farmers who choose to grow black oats in Brazil have only one post-emergent herbicide active ingredient at their disposal, i.e. the acetolactate synthase (ALS)-inhibitor metsulfuron-methyl. Pre-plant burndown using glyphosate is the only other remaining chemical weed control option currently available (Ministério da Agricultura, Pesca e Abastecimento, 2021). This fact complicates proper weed control in this crop, as some weed species evade control following metsulfuron-methyl spraying, potentially causing large yield losses. Additionally, herbicide mode of action rotation is affected severely. Among many herbicide modes of action available for use in the Brazilian market, the so-called 4-HPPD inhibitors (4-hydroxyphenylpyruvate dioxygenase, EC 1.13.11.27; WSSA group 27), which are commonly referred to as bleachers (Figure 1A) and act by inhibiting a key enzyme in the carotenoid biosynthetic pathway, have received great attention and scrutiny in recent years due to their wide use and broad weed control spectrum (Grossmann, Ehrhardt, 2007). 4-HPPD inhibitors such as mesotrione (2-(4-mesyl-2-nitrobenzoyl)cyclohexane-1,3-dione) might also display selectivity to major crops such as sugarcane and maize (Pannacci, Covarelli, 2009). Importantly, to date no case of resistance to 4-HPPD inhibitors have been reported in Brazil (Heap, 2021).

Spraying herbicides earlier into the winter growing season, when most Conyza spp. seedlings emerge, has been shown to facilitate summer crop sowing practices and improve early-growth conditions due to significantly lower weed infestation levels (Oliveira Neto et al., 2010). It also allows for proper herbicide mode of action rotation, potentially delaying or even preventing herbicide resistance evolution. In the present study, we aimed at evaluating crop injury caused by different herbicide treatments (sprayed either alone or as tank-mixtures) as well as G. americana and glyphosate-resistant Conyza spp. control efficacy in the field, such that novel chemical control options for Brazilian black oats can be determined.

\section{Material and Methods}

Three studies (one field and two greenhouse trials) were conducted in 2016 and 2017 in order to determine crop phytotoxicity levels as well as weed control efficacy in real field conditions. All field and greenhouse trials were conducted at an experimental station located in Itaara, RS/ Brazil ( $29^{\circ} 35^{\circ} 06.69^{\prime \prime} \mathrm{S}, 53^{\circ} 48^{`} 28.53^{\prime \prime} \mathrm{W} ; 460 \mathrm{~m}$ elevation). The municipality's climate is classified as a Cfa (humid subtropical) according to the Köppen-Geiger classification, and soil analysis performed at the experimental area indicated average soil organic matter and clay percentages of 3.4 and 27.0, respectively, as well as $<15 \%$ sand. Conyza species in the experimental site were identified following Lazaroto et al. (2008) as a 50:50 mix of Conyza sumatrensis and C. canadensis; such populations were mostly composed of glyphosate-resistant individuals as demonstrated in a study conducted in the previous year in which glyphosate spraying at 1,800 g a.e. ha ${ }^{-1}$ resulted in $85 \%$ plant survival (data not shown).

Black oat seeds were purchased at a local seed supply store; the actual cultivar is referred to as "common" or regular black oats. The crop was drill-seeded on July $10^{\text {th }}$, 2016 in a no-till system with a row spacing of $0.17 \mathrm{~m}$, requiring nearly $80 \mathrm{~kg} \mathrm{ha}^{-1}$ for a harvest density of 3,000,000 plants ha ${ }^{-1}$. Soybeans were grown in the experimental area in the previous summer (late November 2015 through March 2016). Crop fertilization was performed during sowing at a rate of $300 \mathrm{~kg} \mathrm{ha}^{-1}$ of 08-18-28 (NPK ratio), and $150 \mathrm{~kg} \mathrm{ha}^{-1}$ of urea $(46 \% \mathrm{~N})$ were broadcast-applied at the tillering stage.

Eight herbicide treatments (Table 1) plus an untreated control check consisting of distilled water-only were sprayed in the field onto black oat plants in order to determined crop phytotoxicity and weed control efficacy. Rates for all herbicides except saflufenacil and flumioxazin were chosen based on labelled rates at which these herbicides are sprayed onto other crops in order to ensure optimum weed control performance. Since saflufenacil and flumioxazin are commonly sprayed as part of burndown treatments and hence not as postemergence, selective herbicides, their rates were at least $50 \%$ lower than recommended burndown use rates instead (Ministério da Agricultura, Pesca e Abastecimento, 2021) in order to allow for the study of crop selectivity. Conyza spp. density averaged $3.1 \pm 0.8$ plants $\mathrm{m}^{-2}$ (mean $\pm \mathrm{SE}$ ) at the time of herbicide spraying in the field. A separate trial was conducted on October 2016 in a controlledenvironment setting in order to further assess herbicide safety, and did not include 2,4-D and bentazon sprayed alone as well as an imazamox+bentazon premix formulation. Mesotrione was then re-evaluated separately in the second greenhouse study during the following growing season; these trials are hereinafter referred to as greenhouse trials \#1 and \#2, respectively. The actual number of herbicide treatments in greenhouse trial \#1 was decreased relative to the field study since the latter was conducted roughly 10 weeks prior, allowing for the elimination of treatments producing unwanted results (such as severe phytotoxicity or low weed control efficacy).

A $\mathrm{CO}_{2}$-pressurized backpack sprayer calibrated to deliver $150 \mathrm{~L} \mathrm{ha}^{-1}$ at $210 \mathrm{kPa}$ and equipped with a spray 
Table 1 - List of all herbicides (common and trade names) employed in the field trial, as well as application rates ( $\mathrm{g}$ a.i. ${ }^{1}$ or a.e. ${ }^{2}$ ha ${ }^{-1}$ ), and adjuvant concentration (\% v/v) in the spray mixture. An untreated control check consisting of distilled water-only was also included to allow for herbicide phytotoxicity-related impacts onto black oat plants to be determined.

\begin{tabular}{|c|c|c|c|}
\hline Common name & Trade name & $\begin{array}{l}\text { Application rate }{ }^{1} \\
\text { (g a.i. or a.e. ha-1) }\end{array}$ & $\begin{array}{l}\text { Adjuvant } \\
\left(\% \vee v^{-1}\right)\end{array}$ \\
\hline Imazamox+Bentazon² & Amplo & $33.6+720$ & Dash 0.5 \\
\hline 2,4-D amine ${ }^{2}$ & U46 Prime & $502.5^{2}$ & - \\
\hline Saflufenacil & Heat & 21 & Dash 0.5 \\
\hline Bentazon $^{2}$ & Basagran 600 & 720 & Assist $1.0^{3}$ \\
\hline 2,4-D+Bentazon & DMA 806+Basagran & $502.5+720$ & - \\
\hline Flumioxazin & Flumyzin 500 WP & 25 & Dash 0.25 \\
\hline Mesotrione & Callisto & 192 & Assist 0.5 \\
\hline Metsulfuron-methyl & Ally & 3.9 & Assist 0.1 \\
\hline
\end{tabular}

${ }^{1}$.i.i, active ingredient; a.e., acid equivalent; ${ }^{2}$ these treatments were only employed in field trials; ${ }^{3}$ rate expressed in $L$ ha ${ }^{-1}$ rather than $\% v v^{-1}$.

boom and five Teejet 110.02 flat-fan nozzles was used for herbicide applications both in the field and in greenhouse trials. Treatments application was performed at mid-tillering stages, which corrresponded to 48 days after emergence (September 16 ${ }^{\text {th }}, 2016$ ) in the field trial. Environmental conditions during field spraying were recorded using an Extech 45170 Hygro-ThermoAnemometer (FLIR systems Inc., Brazil) and equaled $23{ }^{\circ} \mathrm{C}$ ambient temperature, $74 \%$ R.H., and an average wind speed of $4.5 \mathrm{~km} \mathrm{~h}^{-1}$. Temperatures averaged $21{ }^{\circ} \mathrm{C}$ during treatment application in greenhouse trials.

All studies were designed as randomized complete blocks, replicated four to six times. Experimental units consisted of $15 \mathrm{~m}^{2}$ plots (field trial), whereas greenhouse trials utilized 6 -L plastic pots filled with potting soil. Five black oat seeds were sown per pot, and plants were later thinned to five per experimental unit. G. americana and glyphosateresistant Conyza spp. control as well as crop phytotoxicity were assessed once a week from 7 to 34 days after spraying (DAS) in the field trial, whereas crop phytotoxicity data was measured once a week from 7 to 21 DAS at each greenhouse trial instead. Visual weed control ratings and crop injury followed a percentage scale, at which $0 \%$ indicates lack of any herbicide-induced symptoms, whereas $100 \%$ indicates plant death (weeds) or total yield loss (crop) (Frans 1979). Herbicide-related impacts onto biomass production was evaluated near the end of the crop's life cycle (roughly 100 DAS) in the field by cutting 50 plants plot $^{-1}$ at the soil level; alternatively, all five crop plants were harvested per pot (greenhouse trials). The harvested material was then dried at $60{ }^{\circ} \mathrm{C}$ until constant weight and measurements performed after $96 \mathrm{~h}$ had elapsed.

Following O’Neill-Matthews $(\mathrm{p} \leq 0.05)$ and ShapiroWilk $(\mathrm{p} \leq 0.05)$ tests for data homogeneity and normality, respectively, weed control as well as crop phytotoxicity and biomass data were subject to ANOVA $(p \leq 0.05)$ and means compared using Tukey's HSD test $(\mathrm{p} \leq 0.05)$, when appropriate. Data analysis was performed on R studio (RStudio Team, 2020) using the ExpDes.pt package (Ferreira et al., 2014).

\section{Results and Discussion}

ANOVA results indicated that crop phytotoxicity and dry aboveground biomass levels differed significantly $(\mathrm{p} \leq 0.05)$ across treatment means, indicating herbicides impacted black oat plants' growth differently (Tables 2-4). Despite being the only post-emergent herbicide registered for use in black oats, spraying metsulfuron-methyl has been shown to reduce biomass accumulation of black oats (Dellazen et al., 2015). Here, it resulted in mild crop phytotoxicity which lasted throughout the course of the trial (Table 2). Crop plants appeared stunted and mild leaf chlorosis developed 8-10 days after spraying, which are known ALS inhibitorrelated symptoms (Roman et al., 2007). However, biomass production was not impacted (Table 3 ), indicating crop plants had recovered from the treatment.

Surprisingly, spraying mesotrione resulted in low crop phytotoxicity levels in the field (Table 2) and greenhouse (Table 4) trials, and allowed for crop biomass production levels which matched those of the untreated control check (Table 3), even though it was used at $192 \mathrm{~g}$ a.i. ha- ${ }^{-1}$. This corresponds to $0.4 \mathrm{~L} \mathrm{ha}^{-1}$ of Callisto ${ }^{\circledR}$, which is, in turn, the highest labelled rate and the one expected to allow for the greatest weed control level attainable by this molecule. To further explore mesotrione's selectivity to black oats, the herbicide was then re-evaluated in the next growing season (e.g. greenhouse trial \#2), yielding crop phytotoxicity and biomass production results which resemble those of the untreated control check (Table 5; Figure 1B). Reports in the literature indicate that mesotrione applied either preor post-emergence was also selective to common oats and barley (Hordeum vulgare L.) plants, whereas only applications at pre-emergence displayed sufficient selectivity to wheat (Soltani et al., 2011).

The only herbicide treatment found to significantly decrease black oat biomass production levels was an imazamox + bentazon premix formulation (Table 3), whereas such results paralleled visual crop phytotoxicity levels, at which widespread plant death was recorded at 34 


\begin{tabular}{|c|c|c|c|c|c|c|c|c|c|c|}
\hline \multirow{3}{*}{$\begin{array}{l}\text { Treatment } \\
\text { Untreated check }\end{array}$} & \multicolumn{10}{|c|}{ Evaluation date (days after spraying) } \\
\hline & \multicolumn{2}{|c|}{$7 \mathrm{DAS}$} & \multicolumn{2}{|c|}{13 DAS } & \multicolumn{2}{|c|}{ 21DAS } & \multicolumn{2}{|c|}{28 DAS } & \multicolumn{2}{|c|}{34 DAS } \\
\hline & $0.0^{1}$ & $d^{2}$ & 0.0 & $d$ & 0.0 & $\mathrm{e}$ & 0.0 & $d$ & 0.0 & $d$ \\
\hline Imazamox+Bentazon & 43.7 & $b$ & 82.0 & a & 96.0 & a & 96.2 & a & 100.0 & a \\
\hline 2,4-D amine & 10.0 & $\mathrm{~cd}$ & 0.0 & d & 17.5 & c & 10.0 & c & 11.0 & $\mathrm{~cd}$ \\
\hline Saflufenacil & 37.5 & $b$ & 14.2 & c & 5.5 & de & 0.0 & $d$ & 0.0 & $d$ \\
\hline Bentazon & 4.5 & $d$ & 0 & $d$ & 0.0 & e & 0.0 & $d$ & 0.0 & $d$ \\
\hline 2,4-D+Bentazon & 8.7 & $\mathrm{~cd}$ & 0.0 & $d$ & 12.2 & $\mathrm{~cd}$ & 8.0 & $\mathrm{~cd}$ & 13.7 & $\mathrm{~cd}$ \\
\hline Flumioxazin & 73.7 & a & 28.7 & $b$ & 12.2 & cd & 0.0 & $d$ & 0.0 & $d$ \\
\hline Mesotrione & 12.5 & $\mathrm{~cd}$ & 0.0 & $d$ & 0.0 & e & 0.0 & $d$ & 0.0 & $d$ \\
\hline Metsulfuron-methyl & 27.5 & bc & 28.7 & $b$ & 43.7 & $b$ & 27.5 & $b$ & 33.7 & $b$ \\
\hline
\end{tabular}

${ }^{1}$ Numbers indicate mean values calculated from four replications; ${ }^{2}$ Means followed by the same lower-case letter within columns are not statistically different according to Tukey's HSD test ( $p \leq 0.05)$.

Table 3 - Dry aboveground biomass (DAB, expressed in $\mathrm{kg} \mathrm{ha}^{-1}$ ) accumulated in the field at each treatment

\begin{tabular}{l|c}
\hline Treatment & DAB $\left(\mathrm{kg} \mathrm{ha}^{-1}\right)$ \\
\hline Untreated control & $5062.5 \mathrm{a}^{1}$ \\
\hline Imazamox+Bentazon & $0.0 \mathrm{~b}$ \\
\hline 2,4-D amine & $4687.5 \mathrm{a}$ \\
\hline Saflufenacil & $5562.5 \mathrm{a}$ \\
\hline Bentazon & $5437.5 \mathrm{a}$ \\
\hline 2,4-D+Bentazon & $4187.5 \mathrm{a}$ \\
\hline Flumioxazin & $3812.5 \mathrm{a}$ \\
\hline Mesotrione & $5062.5 \mathrm{a}$ \\
\hline Metsulfuron-methyl & $3650.0 \mathrm{a}$ \\
\hline
\end{tabular}

'Means followed by the same lower-case letter within columns are not statistically different according to Tukey's HSD test ( $p \leq 0.05)$.

DAS (Table 2; Figure 1C). This effect was not observed when bentazon was sprayed alone, strongly suggesting lack of imazamox selectivity to black oats. Interestingly, a similar result was reported by Harker et al. (2007) while studying wild oats (Avena fatua L.). Such results are not unexpected, given that the imazamox + bentazon premix formulation is commonly utilized for grassy weed control in broadleaved crops such as common beans (Phaseolus vulgaris L.) and alfalfa (Medicago sativa L.) (Hekmat et al., 2008).

The protoporphyrinogen oxidase (PPO) inhibitors flumioxazin and saflufenacil caused mild to severe early phytotoxicity levels (Table 2), which declined around 28 DAS and did not impact aboveground biomass production (Table 3). However, as previously mentioned, saflufenacil mand flumioxazin rates used in the present study (Table 1) were at least $50 \%$ lower than recommended use ratesin order to allow for the study of crop selectivity. Based on these results, one can expect that higher rates of both herbicides would damage the crop even further, despite a
Table 4 - Phytotoxicity levels (\%) of treated and untreated black oat plants, recorded at 7, 14, and 21 days after spraying (DAS) at greenhouse trial \#1.

\begin{tabular}{|c|c|c|c|c|c|c|}
\hline \multirow{3}{*}{$\begin{array}{l}\text { Treatment } \\
\text { Untreated check }\end{array}$} & \multicolumn{6}{|c|}{ Crop Phytotoxicity (\%) Greenhouse Trial \#1 } \\
\hline & \multicolumn{2}{|c|}{7 DAS } & \multicolumn{2}{|c|}{14 DAS } & \multicolumn{2}{|c|}{ 21DAS } \\
\hline & $0.0^{1}$ & $d^{2}$ & 0.0 & $\mathrm{~ns}^{3}$ & 0.0 & ns \\
\hline Saflufenacil & 40.0 & $b$ & 9.2 & & 17.5 & \\
\hline 2,4-D+Bentazon & 20.8 & bcd & 5.0 & & 3.3 & \\
\hline Flumioxazin & 80.8 & a & 27.5 & & 16.7 & \\
\hline Mesotrione & 17.5 & $\mathrm{~cd}$ & 7.5 & & 3.3 & \\
\hline Metsulfuron-methyl & 25.5 & bc & 6.7 & & 6.7 & \\
\hline
\end{tabular}

Numbers indicate mean values calculated from six replications; ${ }^{2}$ Means followed by the same lower-case letter within columns are not statistically different according to Tukey's HSD test ( $p \leq 0.05$ ); ${ }^{3} \mathrm{n}$ indicates non-significant values ( $p>0.05$ ) according to ANOVA results obtained for assessments performed at 14 and 21 DAS ( $p=0.081$ and $p=0.67$, respectively).

Table 5 - Herbicide-related crop phytotoxicity levels (\%) determined at 7, 14, and 21 days after spraying (DAS), and dry aboveground biomass (expressed in $\mathrm{g}$ plant ${ }^{-1}$ ) measured at the end of greenhouse trial \#2.

\begin{tabular}{|c|c|c|c|c|c|c|c|c|}
\hline \multirow[t]{2}{*}{ Treatment } & \multicolumn{6}{|c|}{$\begin{array}{c}\text { Crop Phytotoxicity (\%) Greenhouse } \\
\text { Trial \#2 }\end{array}$} & \multirow{2}{*}{\multicolumn{2}{|c|}{$\begin{array}{c}\text { DAB } \\
\text { (g plant }{ }^{-1} \text { ) }\end{array}$}} \\
\hline & $7 \mathrm{D}$ & & 14 & & & & & \\
\hline $\begin{array}{l}\text { Untreated } \\
\text { control }\end{array}$ & $0.0^{1}$ & \multirow[t]{2}{*}{$n s^{2}$} & 0.0 & \multirow[t]{2}{*}{ ns } & 0.0 & \multirow[t]{2}{*}{ ns } & 66.0 & \multirow[t]{2}{*}{ ns } \\
\hline Mesotrione & 1.2 & & 2.0 & & 2.5 & & 63.4 & \\
\hline
\end{tabular}

Numbers indicate mean values based on four replications; ${ }^{2} \mathrm{n}$ indicates non-significant values ( $p>0.05$ ) according to ANOVA results obtained for both crop phytotoxicity and DAB variables.

positive impact on weed control efficacy. Thus, their use in black oats as post-emergence treatments seems unlikely, given that the actual rates needed for efficient weed control are significantly above those employed at the present work. 


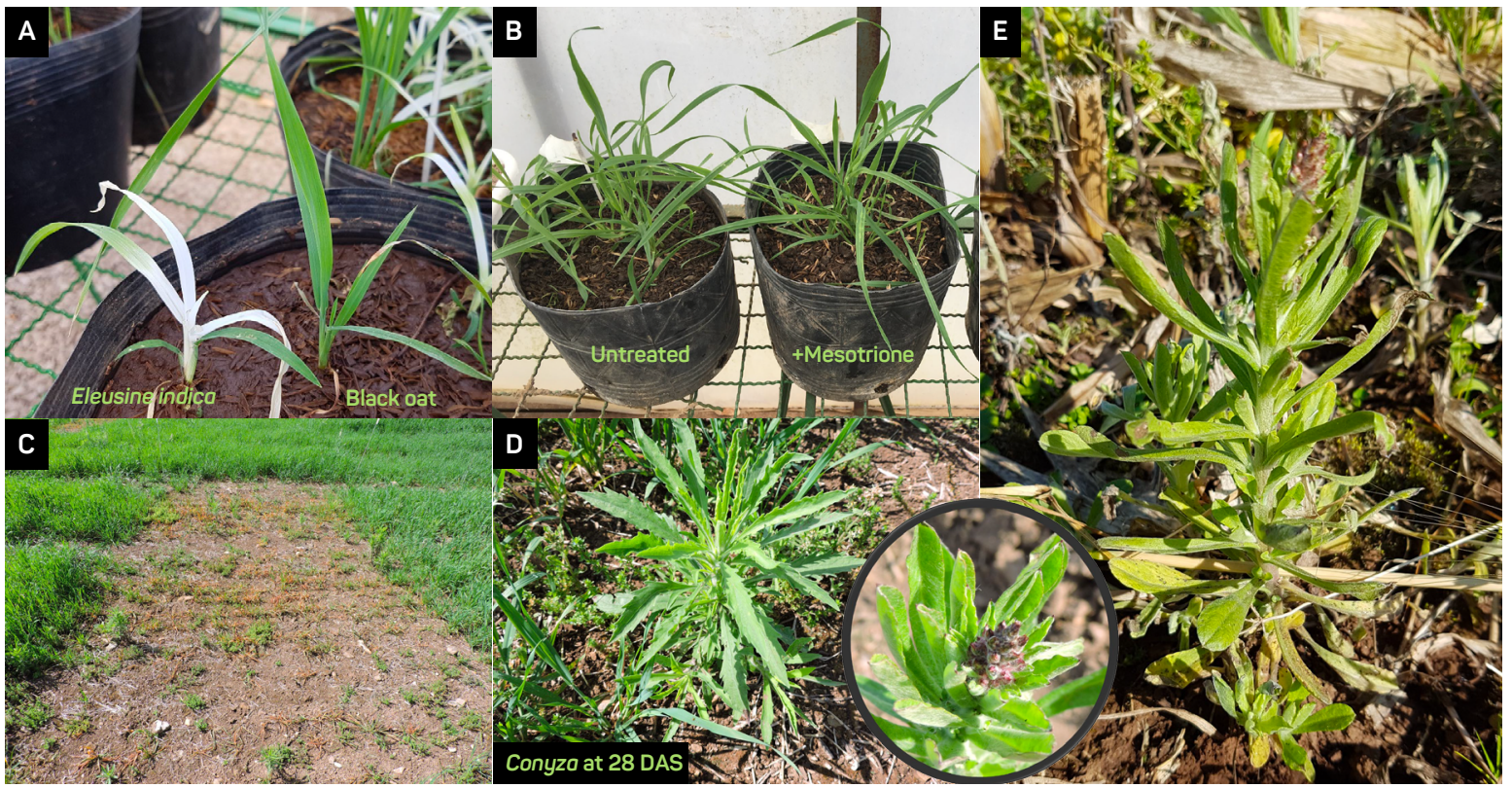

Figure 1 - (A) Mesotrione-treated black oat plant alongside goosegrass (Eleusine indico (L). Gaertn.) plant demonstrating typical bleaching symptoms set forth by applications of 4-HPPD inhibitors such as mesotrione; (B) Similar-looking treated and untreated black oat plants 21 days after mesotrione spraying in greenhouse trial \#2; (C) Overall appearance of a field plot which had been sprayed with an imazamox + bentazon premix formulation 28 days earlier; ( $D$ and E) Glyphosate-resistant Conyzo sp. (D) and Gamoachoeto americano (E) plants found growing in untreated control plots, 28 days after treatment spraying was performed. At the lower right-hand side, a close-up photo of G. americana's inflorescence.

Table 6 - Glyphosate-resistant Conyzo spp. control levels (\%) recorded from 7 to 34 days after herbicide spraying in the field.

\begin{tabular}{|c|c|c|c|c|c|c|c|c|c|c|}
\hline \multirow{3}{*}{$\begin{array}{l}\text { Treatment } \\
\text { Untreated control }\end{array}$} & \multicolumn{10}{|c|}{ Glyphosate-resistant Conyza spp. Control (\%) } \\
\hline & \multicolumn{2}{|c|}{7 DAS } & \multicolumn{2}{|c|}{13 DAS } & \multicolumn{2}{|c|}{ 21DAS } & \multicolumn{2}{|c|}{28 DAS } & \multicolumn{2}{|c|}{34 DAS } \\
\hline & $0^{1}$ & $c^{2}$ & 0 & $d$ & 0 & $d$ & 0 & d & 0 & C \\
\hline Imazamox+Bentazon & 99 & a & 80 & $a b$ & 45 & c & 19 & $\mathrm{~cd}$ & 6 & c \\
\hline 2,4-D amine & 99 & a & 83 & $a b$ & 84 & $a b$ & 73 & $a b$ & 73 & b \\
\hline Saflufenacil & 99 & a & 85 & $a b$ & 83 & $a b$ & 67 & $b$ & 15 & c \\
\hline Bentazon & 85 & a & 64 & bc & 56 & C & 33 & c & 20 & c \\
\hline 2,4-D+Bentazon & 99 & a & 96 & a & 90 & $a b$ & 91 & $a b$ & 72 & $b$ \\
\hline Flumioxazin & 65 & $b$ & 19 & $\mathrm{~cd}$ & 9 & $d$ & 0 & $d$ & 0 & c \\
\hline Mesotrione & 99 & a & 92 & a & 96 & a & 94 & a & 99 & a \\
\hline Metsulfuron-methyl & 92 & a & 22 & $\mathrm{~cd}$ & 75 & $b$ & 71 & $a b$ & 77 & $b$ \\
\hline
\end{tabular}

${ }^{1}$ Numbers indicate mean values calculated from four replications; ${ }^{2}$ Means followed by the same lower-case letter within columns are not statistically different according to Tukey's HSD test $(\alpha=0.05)$

Table 7 - Gamochaeto americano control levels (\%) recorded from 7 to 34 days after herbicide spraying in the field.

\begin{tabular}{|c|c|c|c|c|c|c|c|c|c|c|}
\hline \multirow{3}{*}{$\begin{array}{l}\text { Treatment } \\
\text { Untreated check }\end{array}$} & \multicolumn{10}{|c|}{ Gamochaeta americana Control (\%) } \\
\hline & \multicolumn{2}{|c|}{7 DAS } & \multicolumn{2}{|c|}{13 DAS } & \multicolumn{2}{|c|}{$21 \mathrm{DAS}$} & \multicolumn{2}{|c|}{28 DAS } & \multicolumn{2}{|c|}{34 DAS } \\
\hline & $0^{1}$ & $c^{2}$ & 0 & $d$ & 0 & $b$ & 0 & $b$ & 0 & $\mathrm{C}$ \\
\hline Imazamox+Bentazon & 94 & $a b$ & 91 & a & 80 & a & 64 & a & 100 & a \\
\hline 2,4-D amine & 45 & bc & 20 & $\mathrm{~cd}$ & 14 & $b$ & 0 & $b$ & 0 & c \\
\hline Saflufenacil & 99 & a & 86 & $a b$ & 74 & a & 81 & a & 57 & b \\
\hline Bentazon & 95 & $a b$ & 81 & $a b$ & 77 & a & 58 & a & 0 & c \\
\hline 2,4-D+Bentazon & 99 & a & 87 & $a b$ & 91 & a & 75 & a & 28 & bc \\
\hline Flumioxazin & 75 & $a b$ & 25 & $\mathrm{~cd}$ & 10 & $b$ & 0 & $b$ & 0 & c \\
\hline Mesotrione & 87 & $a b$ & 46 & a & 93 & a & 100 & a & 100 & a \\
\hline Metsulfuron-methyl & 51 & $a b c$ & 46 & bc & 56 & a & 98 & a & 100 & a \\
\hline
\end{tabular}

${ }^{1}$ Numbers indicate mean values calculated from four replications; ${ }^{2}$ Means followed by the same lower-case letter within columns are not statistically different according to Tukey's HSD test ( $\alpha=0.05$ ). 
The remaining treatments (i.e. 2,4-D, bentazon, and a 2,4-D + bentazon tank-mix) resulted in light crop phytotoxicity and did not impact biomass accumulation (Tables 2 and 3, respectively), and hence could become broadleaf weed control tools. These results corroborate Vargas and Roman (2005) indicating 2,4-D and bentazon selectivity to winter cereals such as barley, black oats and even Italian ryegrass (Lolium perenne L. spp. multiflorum) used for forage purposes in Southern Brazil.

Mesotrione was the only herbicide treatment achieving satisfactory (>80\%) levels of glyphosate-resistant Conyza spp. control at 34 DAS. This was followed by metsulfuronmethyl and 2,4-D applied either alone or tank-mixed with bentazon, which resulted in control levels above $70 \%$ while also preventing weed regrowth. Interestingly, all metsulfuron methyl-based products sold in Brazil are not labelled for Conyza spp. control (Ministério da Agricultura, Pesca e Abastecimento, 2021). Moreover, weed control efficacy following flumioxazin or saflufenacil applications were likely impaired by lower-than-recommended rates employed in this study, and might not reflect their true ability to control these species. However, satisfactory G. americana control was only realized via applications of mesotrione, metsulfuron-methyl, or an imazamox + bentazon premix formulation suggesting some degree of tolerance to 2,4-D herbicide which was not previously identified in the literature and remains to be elucidated.

2,4-D is widely used to improve glyphosate-resistant Conyza spp. control during summer crop pre-plant burndown or during winter months, when some fields are left fallow (Oliveira Neto et al., 2010). However, due to recent reports of simultaneous resistance to 2,4-D, glyphosate, PPO, and ALS inhibitors in Brazilian C. sumatrensis biotypes (Heap, 2021), growers are advised to spray herbicides with different modes of action, as well as implementing integrated weed management control practices. In this scenario, postemergence applications of the 4-HPPD inhibitor mesotrione could constitute a new option for weed management in black oats, aiding in the fight against multiple-herbicide resistant Conyza spp. which grow during late autumn and winter months. Its use, however, is pending further studies for registration as required by the country's law.

To our knowledge, this is the first report of selectivity to mesotrione in black oats. Given that results by
Cargnin et al. (2015) pointed toward different levels of tolerance to herbicides among common oat genotypes, ongoing research efforts are aimed at determining responses of black oat cultivars to a wide range of herbicides as well as understanding the mechanism(s) of mesotrione tolerance demonstrated by this crop.

\section{Conclusions}

Applications of mesotrione as well as 2,4-D, either alone or tank-mixed with bentazon, are safe for black oat plants when performed during mid-tillering stages while also allowing for excellent glyphosate-resistant Conyza spp. control; with the former also effective for controlling G. americana. In the wake of a troubling case of resistance to multiple herbicides including 2,4-D and PPO inhibitors in Conyza sumatrensis, growers have been strongly advised to spray herbicides with different modes of action and alternate these. In this scenario, the 4-HPPD inhibitor mesotrione might represent an option for post-emergence weed control in black oat fields, aiding in the fight against multiple-herbicide resistant Conyza spp. which grow during late autumn and winter months.

\section{Author's contributions}

RMP and RCAN: conceptualization of the manuscript and development of the methodology; data collection and curation; data analysis; data interpretation; funding acquisition and resources: not related to this project; writing the original draft of the manuscript. RMP: project administration; supervision. RMP, RVF, DDN, and RCAN: writing, review and editing: All authors read and agreed to the published version of the manuscript.

\section{Acknowledgements}

The authors would like to thank Gustavo Menezes Cezar and Marcos Stefanello Murari, UFSM undergraduate students at the time, for their help and support during field and greenhouse trials.

\section{Funding}

This research received no external funding.

\section{References}

Borges RAX, Heiden G, Teles AM. [List of Brazilian flora species: Conyzo sumatrensis (Retz.) E.Walker]. Reflora: Flora do Вrasil. Sept 29, 2014[access Mar 7, 2021]. Portuguese. Available from: http://floradobrasil.jbrj.gov.br/jabot/floradobrasil/FB5288

Cargnin A, Santos LDT, Pinto JJO, Sofiatti V. [Use of selective herbicides in white oat]. Rev Ceres. 2015;53(306):139-43. Portuguese.
Companhia Nacional de Abastecimento - Conab. [Oat Brazil: historical series of planted area: crop 1976 to 2021]. Brasília: Companhia Nacional de Abastecimento; 2021[access Mar 1, 2021]. Portuguese. Available from: https://www.conab.gov.br/info-agro/safras/serie-historica-das-safras/item/7686-aveia

Ferreira EB, Cavalcanti PP, Nogueira DA. ExpDes: an R package for anova and experimental designs. Appl Math. 2014;5(19):2952-8. Available from: https://doi.org/10.4236/am.2014.519280 
Grossmann K, Ehrhardt T. On the mechanism and selectivity of the corn herbicide topramezone: a new inhibitor of 4-Hydroxyphenylpyruvate dioxygenase. Pest Manag Sci. 2007;63(5):429-39. Available from: https://doi.org/10.1002/ps.1341

Hao JH, Qiang S, Liu QQ, Cao F. Reproductive traits associated with invasiveness in Conyzo sumatrensis. J Syst Evol. 2009;47(3):245-54. Available from: https://doi.org/10.1111/j.1759-6831.2009.00019.x

Harker KN, Blackshaw RE, Clayton GW. Wild oat (Aveno fatua) vs redstem filaree (Erodium cicutarium) interference in dry pea. Weed Technol. 2007;21(1):235-40. Available from: https://doi. org/10.1614/WT-06-093.1

Heap I. The international survey of herbicide resistant weeds. Weedscience. 2021[access Mar 8, 2021]. Available from: www.weedscience.org

Hekmat S, Soltani N, Shropshire C, Sikkema PH. Effect of imazamox plus bentazon on dry bean (Phoseolus vulgaris L.). Crop Protect 2008;27(12):1491-4. Available from: https://doi.org/10.1016/j.cropro.2008.07.008

Hussain Z, Bahadar-Marwat K, Cardina J. Common cocklebur competition in forage maize. Weed Technol. 2011;25(1):151-8. Available from: https://doi.org/10.1614/WT-D-10-00092.1

Lazaroto CA, Fleck NG, Vidal RA. Biology and ecophysiology of hairy fleabane (Conyza bonariensis) and horseweed (Conyza canadensis). Cienc Rural. 2008;38(3):852-60. Available from: https://doi. org/10.1590/S0103-84782008000300045

Loeuille BFP. [Gomochaeto americano (Mill.) Wedd]. Reflora: Flora do Brasil. 2020[access Feb 18, 2021]. Portuguese. Available from: http://floradobrasil.jbrj.gov.br/reflora/floradobrasil/FB106771

Martins D, Gonçalves CG, Silva Jr AC. [Winter mulches and chemical control on weeds in maize]. Rev Cienc Agron. 2016;47(4):649-57. Portuguese. Available from: https://doi.org/10.5935/1806-6690.20160078

Ministério da Agricultura, Pesca e Abastecimento (BR). [Agrofit: phytosanitary pesticides system]. Brasília: Ministério da Agricultura, Pesca e Abastecimento; 2021[access Mar 6, 2021]. Portuguese. Available from: http://agrofit.agricultura.gov.br/
Oliveira Neto AM, Guerra N, Dan HA, Braz GBP, Jumes TMC, Santos $G$ et al. [Conyzo bonoriensis management with glyphosate + 2,4-D and glufosinate according to development stage] Rev Bras Herb. 2010;9(3):73-80. Portuguese. Available from: https://doi.org/10.7824/rbh.v9i3.87

Pannacci E, Covarelli G. Efficacy of mesotrione used at reduced doses for post-emergence weed control in maize (Zeo mays L.). Crop Protect. 2009;28(1):57-61. Available from: https://doi.org/10.1016/j.cropro.2008.08.011

Piza CST, Nepomuceno MP, Alves PLCA. Period prior to interference of morning glory in sugarcane. Científica. 2016;44(4):543-8. Available from: https://doi.org/10.15361/1984-5529.2016v44n4p543-548

Pruski JF, Sancho G. Conyzo sumatrensis var. leiotheco (Compositae: Asteraceae), a new combination for a common neotropical weed. Novon. 2016;16(1):96-101.

Queiroz ARS, Delatorre CA, Lucio FR, Rossi CVS, Zobiole LHS, Merotto Jr A. Rapid necrosis: a novel plant resistance mechanism to 2,4-D. Weed Sci. 2020;68(1):6-18. Available from: https://doi.org/10.1017/wsc.2019.65

Roman ES, Beckie H, Vargas L, Hall L, Rizzardi MA, Wolf T. [How herbicides work: from biology to application]. Passo Fundo: Berthier; 2007. Portuguese.

RStudio Team. RStudio: integrated development for R. Boston: RStudio; 2020[access Mar 5, 2021]. Available from: www.rstudio.com

Russell DP, Byrd JD, Zaccaro MLM. Preemergence and postemergence control of Perilla Mint (Perilla frutescens): avoiding toxicity to livestock. Weed Technol. 2018;32(3):290-6. Available from: https://doi.org/10.1017/wet.2018.12

Soltani N, Shropshire C, Sikkema PH. Response of spring planted barley (Hordeum vulgare L.), oats (Aveno sotivo L.) and wheat (Triticum oestivum L.) to mesotrione. Crop Protect. 2011;30(7):849-53. Available from: https://doi.org/10.1016/j.cropro.2011.03.023

Vargas L, Roman ES. [Selectivity and efficacy of herbicides to winter cereals]. Rev Bras Herb. 2005;4(3):1-10. Portuguese. Available from: https://doi.org/10.7824/rbh.v4i3.32 